\title{
Self-Managing Osteoporosis Treatment for Well-Being Recovery Mediated by the (in)visibility of the Disease Signs
}

\author{
Luciana Bronzi de Souza $^{1}$ \\ Gláucia Maria Ferreira da Silva Mazeto² \\ Silvia Cristina Mangini Bocchi ${ }^{3}$
}

The present study aimed to understand patients' experience with osteoporosis treatment. The methodological and theoretical frameworks were, respectively, the Grounded Theory and Symbolic Interactionism. The research subjects were 12 patients monitored in a specialized outpatient unit. The obtained statements were transcribed and analyzed, leading to a synthesis of the described themes. From the analysis process, two phenomena emerged: "self-evaluating health conditions according to the disease signs" and "making a decision about the treatment targeting at well-being". The realignment and the inter-relationship of the components belonging to these phenomena (themes, categories, and subcategories) allowed to identify the core category: "self-managing osteoporosis treatment for well-being recovery mediated by the (in)visibility of the disease signs". Furthermore, it allowed for the design of a theoretical model concerning the process used by the player in his cyclic movement of the experience, between adherence to and relaxation from the osteoporosis treatment.

Descriptors: Osteoporosis; Patient Compliance; Qualitative Research; Treatment Outcome; Chronic Disease.

\footnotetext{
Universidade Estadual Paulista "Júlio de Mesquita Filho", UNESP, Botucatu, SP, Brazil:

${ }^{1}$ Nutrition Undergraduate Student, Instituto de Biociências de Botucatu. E-mail: lubronzi@hotmail.com.

2 Physician, PhD, Assistant Professor, Departamento de Clínica Médica, Faculdade de Medicina de Botucatu. E-mail: gmazeto@fmb.unesp.br.

3 RN, Ph.D. in Nursing, Assistant Professor, Departamento de Enfermagem, Faculdade de Medicina de Botucatu. E-mail: sbocchi@fmb.unesp.br.
}

Corresponding Author:

Glaucia Maria Ferreira da Silva

UNESP - Faculdade de Medicina de Botucatu

Rua Campus de Botucatu, S/N

Distrito de Rubião Júnior

CEP: 18618-000 Botucatu, SP, Brasil

E-mail: gmazeto@fmb.unesp.br 


\section{Autogerindo o tratamento da osteoporose no regaste do bem-estar, mediado pela (in)visibilidade de indicadores da doença}

O presente estudo teve como objetivo compreender a experiência dos pacientes com o tratamento da osteoporose. Os referenciais metodológico e teórico foram, respectivamente, a Grounded Theory e o Interacionismo Simbólico. A amostra desta pesquisa foi composta por 12 pacientes, acompanhados em um ambulatório especializado. Dos depoimentos obtidos, após transcritos e analisados, obteve-se uma síntese dos temas descritos. Do processo de análise, emergiram dois fenômenos: "autoavaliando o estado de saúde, segundo os indicadores da doença" e "tomando a decisão quanto ao tratamento, tendo como meta o bem-estar". O realinhamento e a inter-relação de componentes, pertencentes a esses fenômenos (temas, categorias e subcategorias), possibilitaram identificar a categoria central, denominada "autogerindo o tratamento da osteoporose no regaste do bem-estar, mediado pela (in)visibilidade de indicadores da doença". Ademais, permitiu elaborar um modelo teórico referente ao processo empreendido pelo ator no seu movimento cíclico da experiência, entre a adesão e o relaxamento quanto ao tratamento da osteoporose.

Descritores: Osteoporose; Cooperação do Paciente; Pesquisa Qualitativa; Resultado de Tratamento; Doença Crônica.

\section{Auto-administrando el tratamiento de la osteoporosis en el rescate del bienestar, mediado por la (in)visibilidad de indicadores de la enfermedad}

Este estudio tuvo como objetivo comprender la experiencia de los pacientes con el tratamiento de la osteoporosis. Los marcos teórico y metodológico fueron, respectivamente, la Grounded Theory y el Interaccionismo Simbólico. Los sujetos fueron 12 pacientes en una clínica especializada. Las declaraciones fueron transcritas y analizadas, habiendo sido obtenida una síntesis de los temas descritos. En el proceso de análisis surgieron dos fenómenos: "auto-evaluando el estado de salud de acuerdo a los indicadores de la enfermedad" $\mathrm{y}$, "tomando una decisión sobre el tratamiento teniendo como meta el bienestar". La reestructuración y la interrelación de los componentes que pertenecen a estos fenómenos (temas, categorías y subcategorías) permitieron identificar la categoría central, llamada "auto-administrando el tratamiento de la osteoporosis en el rescate del bienestar, por medio de la (in)visibilidad de los indicadores de la enfermedad." Además, permitió elaborar un modelo teórico referente al proceso emprendido por el actor en su movimiento cíclico da experiencia, entre la adhesión y el relajamiento en lo que se refiere al tratamiento de la osteoporosis.

Descriptores: Osteoporosis; Cooperación del Paciente; Investigación Cualitativa ; Resultado del Tratamiento; Enfermedad Crónica.

\section{Introduction}

This study emerges from the authors' experience of working on a multiprofessional team and at an outpatient unit specialized in osteometabolic diseases, where osteoporosis has been a prevalent diagnosis, contextualized in a country that has experienced the phenomenon of population ageing, similarly to all other nations in Latin America and the Caribbean ${ }^{(1-2)}$
Osteoporosis is usually defined as a disease characterized by mass reduction and micro-architecture deterioration in bone tissue, leading to increased tissue fragility and, as a result, increased risk of fractures ${ }^{(3)}$. It is the most common osteometabolic disease and an important public health problem in other countries, affecting more than 200 million women worldwide. Also, 
according to the National Osteoporosis Foundation, 22 million postmenopausal women, aged 55 years or older, present the disease and, of these, 78\% are not

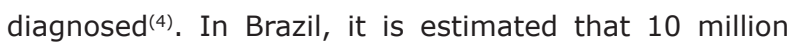
individuals have osteoporosis and that 2.4 million will suffer some type of fracture every year ${ }^{(3)}$.

Effective osteoporosis treatments have been available for more than 10 years. Although clinical research shows the benefits of such therapeutic schemes, efficacy is lower in patients who do not fully adhere to therapy. Based on studies, these authors show that $50 \%$ of patients no longer adhere after the first year of therapy and that low persistence and adherence are associated with increased fracture rates ${ }^{(5)}$.

Studies exploring the barriers to individuals' adherence to osteoporosis treatment show that people do not consider the disease as a relevant health care problem because it develops silently, differently from other pathologies that are initially presented by manifestations $^{(6)}$. This is added to their lack of knowledge concerning one's susceptibility with ageing and the belief that it is a normal process in elderly persons' lives $^{(7)}$.

As a result, it is common for health care professionals to find individuals who are surprised by the disease when it is already at an advanced stage, signaled by fracture(7-8), significant pain $^{(7)}$ and altered radiodiagnostic test results ${ }^{(9)}$. Not even the fact that an individual may show osteoporosis-associated recurrent fractures ensures that he or she will develop the perception of risk for new episodes. A study reports that $54 \%$ of patients with recurrent fractures were not able to relate them to osteoporosis(6).

The literature recommends that health care professionals should endeavor to put in practice strategies that can contribute to the reduction of such barriers ${ }^{(10)}$, based on continuing education processes ${ }^{(11)}$.

In view of the Brazilian population's ageing, the prevalence of the disease and low adherence to osteoporosis treatment as well as the importance of performing studies on this subject(5) and, as an attempt to further the knowledge that will provide a basis for educational actions, we decided to begin our investigation process with the following question: "How is the experience of an individual undergoing osteoporosis treatment constituted?". By conducting this study, we intend to understand the interactional experience of individuals undergoing osteoporosis treatment and develop a representative theoretical model of such experience in the light of the methodological and theoretical frameworks of qualitative research.

\section{Method}

This is a qualitative study approved by the Research Ethics Committee of the Botucatu School of Medicine, process No 396/2008-CEP. It was conducted among osteoporosis patients under clinical follow-up for over a year at the Calcium Disorders Outpatient Unit of the Botucatu School of Medicine, São Paulo State University, Brazil.

Data collection began after Free Consent for Research Participation was obtained from the participants. Nonstructured interviews were conducted and taperecorded according to the following guiding question: "What has your experience with osteoporosis treatment been like?" The obtained statements were transcribed and the tapes were later destroyed.

The methodological framework used was Grounded Theory: discovering categories, connecting categories, developing memos and identifying the process(12). We emphasize that, in this methodological framework, data collection takes place simultaneously with the analytical process, until the researcher attains theoretical saturation, that is, until no relevant data emerge from the analysis, thus showing categories developed in terms of properties and dimensions and relationships between them that are well established and validated by the data themselves ${ }^{(12)}$. In the present study, theoretical saturation occurred with the analysis of the $12^{\text {th }}$ interview, with 11 women and 1 man, with ages ranging from 36 to 79 years.

The experience of the players undergoing osteoporosis treatment was analyzed in the light of Symbolic Interactionism. Four important aspects distinguish this theoretical framework from others in psychology: "1 - Symbolic Interactionism creates a more active image of the human being and rejects the image of a passive and determined organism. 2 - the human being is understood as someone acting in the present, who is influenced not only by what happened in the past, but also by what is happening now. 3 - interaction is not only what is happening among people, but also what is taking place within individuals. This definition may be influenced by those whom we interact with. It is also the result of our own definition, our interpretation of the situation. 4 - Symbolic Interactionism describes human beings as more active in their world than in other perspectives. The concepts of Symbolic Interactionism are: symbol, self, mind, assuming the other's role, human action and social interaction ${ }^{(13)}$. 


\section{Results: the Interactional Experience of the Individual Undergoing Osteoporosis Treatment}

Data analysis according to the Grounded Theory enabled us to understand the interactional experience of the individual undergoing osteoporosis treatment by means of two phenomena ( $A$ and $B$ ).

\section{Phenomenon A. Self-evaluating Health Conditions According to Disease Signs}

It is the continuous process of self-evaluation conducted by the individual about his health conditions, based on the manifestations of osteoporosis, as well as his behavior in relation to treatment that will indicate the visibility or not of the disease in his life. While evidence is not revealed to the individual, he perceives himself as being well and, therefore, the disease also continues to occupy an invisible place in his everyday life. The opposite occurs to those who are confronted with the confirmation of the disease, in the face of the difficult experience of beginning to live with the manifestations of osteoporosis. This phenomenon integrates two themes $(A 1, A 2)$.

Theme A1. Perceiving Oneself Well When not Experiencing Manifestations of the Disease

It means the experience of the individual whose osteoporosis has been diagnosed, but since he cannot feel it through clinical manifestations of the disease, he remains independent in everyday activities, without perceiving it as a disturbance to his daily life. This theme involves two categories (A1.1, A1.2).

Category A1.1. Not Showing Significant Alterations in Everyday Activities

These are experiences in which individuals do not feel significant limitations to their everyday activities; therefore, these individuals enjoy total independence and autonomy in the face of a disease that is still configured as something invisible in their lives: $[\ldots] I$ avoid lifting heavy things. You know [...] I also try not to exaggerate [...], but I work, I do my things normally [...] this hasn't changed anything in my life [...] (Actor 5); [...] for me, there were no changes after (the diagnosis of) the osteoporosis [...] (Actor 2); [...] I go to the vegetable garden in the morning and keep waiting for the sunrise to sunbathe in the morning. I stay there twiddling, twiddling and then I go home and there I do everything I've got to do [...] (Actor 3).
Category A1.2. Not Perceiving Oneself With Indications

Related to the Development of the Disease

These are individuals who have been diagnosed with osteoporosis, but are not living with clinical manifestations of the disease as signals for health care. This category joins three sub-categories: not having experienced fractures; not feeling pain; not perceiving postural alterations: [...] you know! I fall down, but I don't have problems. I've really had some bad falls, but I've never broken any bones [...] I don't know how long I've had osteoporosis, but thank God, I don't feel any pain. [...]. My health is very good (Actor 6); [...] in posture, I haven't noticed anything, but I always try to stand up straighter, not to bend down very much [...] (Actor 10); [...] I have had osteoporosis for 11 years and throughout this time I've never broken anything [...] (Actor 5); [...] I don't feel any pain [...] Nothing at all! I don't feel anything $[\ldots]$ (Actor 9).

Theme A2. Perceiving Oneself as Being Discouraged When Finding Oneself Affected by the Disease

This is how an individual who had been feeling well despite the osteoporosis diagnosis and then begins to live with manifestations of the disease sees himself. He expresses sadness when facing the disease, concretely revealed by evidence like: results of bone densitometry tests showing bad development of the disease, pain, fractures, postural alterations and limitations to activities in everyday living. This theme integrates two categories (A2.1, A2.2).

\section{Category A2.1. Perceiving Oneself With Manifestations of the Disease}

This is how an individual begins to see himself when living with the revealing evidence of the natural course of osteoporosis, manifested through the following sub-categories: bone densitometry signaling worse disease conditions after treatment interruption; feeling pain; being afraid of falls and experiencing fractures; showing postural alterations; experiencing limitations in activities of daily living as a result of the disease: [...] for a year and a half, two years, I didn't take anything, not even calcium. But then I had a bone densitometry test done, and my osteoporosis had really increased. After that, I began to take it again, and now I'm taking it regularly [...]. (Actor 1); [...] it hurts a lot! If I walk a long way, hang up clothes to dry, I hurt all over! (Actor 10); [...] I feel a lot of pain, in my legs and in my fingers [...] (Actor 11); [...] my fracture was 
in the arm, it only cracked, and the other day, I fell and broke my hip-bone in two places. I had to rest for 20 days [...] (Actor 10); [...] I stoop almost all the time, but I think it's become worse because of osteoporosis [...]. I've shrunk [...] (Actor 11); [... I am more limited; there are a few things that I used to do that I don't do anymore because the doctor has told me not to $[\ldots]$ (Actor 4).

Category A2.2. Feeling Sad When Finding Oneself With Osteoporosis

It is an unpleasant feeling that results from experiencing the manifestations of the disease, signaling to the individual that his development is taking an unfavorable course in the health-disease process and, therefore, it is necessary to resume treatment in the attempt to recover the feeling of well-being: [...] To me, it's sad to know that I have osteoporosis [...], but after I started treatment here, I've been feeling better (Actor 7); [...] I was sad when I found out about osteoporosis [...]. I was afraid I might have it because I know it has no solution [...] and today, I feel really sad at night [...], sometimes, I even cry [...] (Actor 11).

\section{Phenomenon B. Making a Decision About the Treatment With Wellbeing as a Goal}

This is the attitude taken by an individual in the face of osteoporosis treatment, which results from the process of self-evaluation of his health condition, mediated by the visibility or not of osteoporosis signs in his experience. If the individual perceives himself as being affected, that is, the disease has become a concrete fact in his life, he will take action in order to recover his wellbeing by following the treatment recommended by healthcare professionals. However, when the disease signs disappear, because he is experiencing unpleasant situations related to the treatment, he tends to relax it in an attempt to experience full wellbeing for a period of time until recurrence of manifestations takes place, which will force him to resume the recommended treatment. This phenomenon includes three categories (B1, B2, B3).

Category B1. Relaxing the Treatment in Search of Full Wellbeing

It is the attitude taken by the individual who has been diagnosed with osteoporosis and experiences a state of wellbeing in relation to evidence of the disease, such as: pain, postural alterations, fractures, but still lives with unpleasant situations related to the medication or non-medication treatment that he has undertaken.
As a result, he decides to relax or abandon it so as to enjoy, for a period of time, full wellbeing, that is, by not experiencing any unpleasant sensations, thus making the disease invisible in his daily life. This category joins two sub-categories: abandoning the recommended diet because of considering it beyond his possibilities of consumption; interrupting medication treatment in the face of side effects: [...] the dietitians recommend that $I$ eat white cheese, but I don't eat much of it because it doesn't do me good. I'm allergic to it, and it gives me migraine [...] (Actor 2); [...] I have little cheese and milk because I can't buy them. I buy milk more often, but I seldom buy greens or cheese [...] (Actor 8); I couldn't take the medicines anymore, because I started to have cough, heartburns and even vomited a little [...]. I didn't take anything for about two years. I wanted to take a break from the medication. Then, I started to take it again $[\ldots]$ (Actor 1 ).

Category B2. Resuming Treatment When Experiencing Manifestations of the Disease, in Search of Wellbeing

It is the decision to take the responsibility to adhere and follow the recommendations given by the multiprofessional team in relation to the treatment with the purpose of fighting the manifestations of the disease by taking two attitudes, which are represented by the sub-categories: taking medication correctly and consuming the recommended diet: [...] I try to take the medication at the right time so as not to mess up the treatment [...] (Actor 3); [...] I drink milk everyday, I eat cheese, and I eat greens too [...] (Actor 6); [...] what I can do, I do, I always buy what is possible and I try to eat well [...] (Actor 10).

\section{Category B3. Recovering wellbeing}

It is the phase of the experience in which the individual realizes that he is being successful in recovering the desired wellbeing by adhering to treatment in the face of the difficult situation of being affected by the disease: [...] After I began treatment here [...], I've been feeling better, because I used to feel terrible pain [...] I hurt all over [...] and now I feel pain sometimes, but it's weak [...] pain has decreased with this treatment [...] (Actor 7).

\section{Discovering the core category}

The strategy used to discover the core category was to inter-relate the two phenomena "Self-evaluating health conditions according to disease signs" and "Making a decision about the treatment with wellbeing as a goal", trying to compare and analyze them in order to understand how the interaction between their components occurred. This strategy enabled us to 
identify the categories and the key sub-categories which pointed out the individual's movement in relation to osteoporosis treatment, as well as to obtain the core category, as presented in Figure 1.

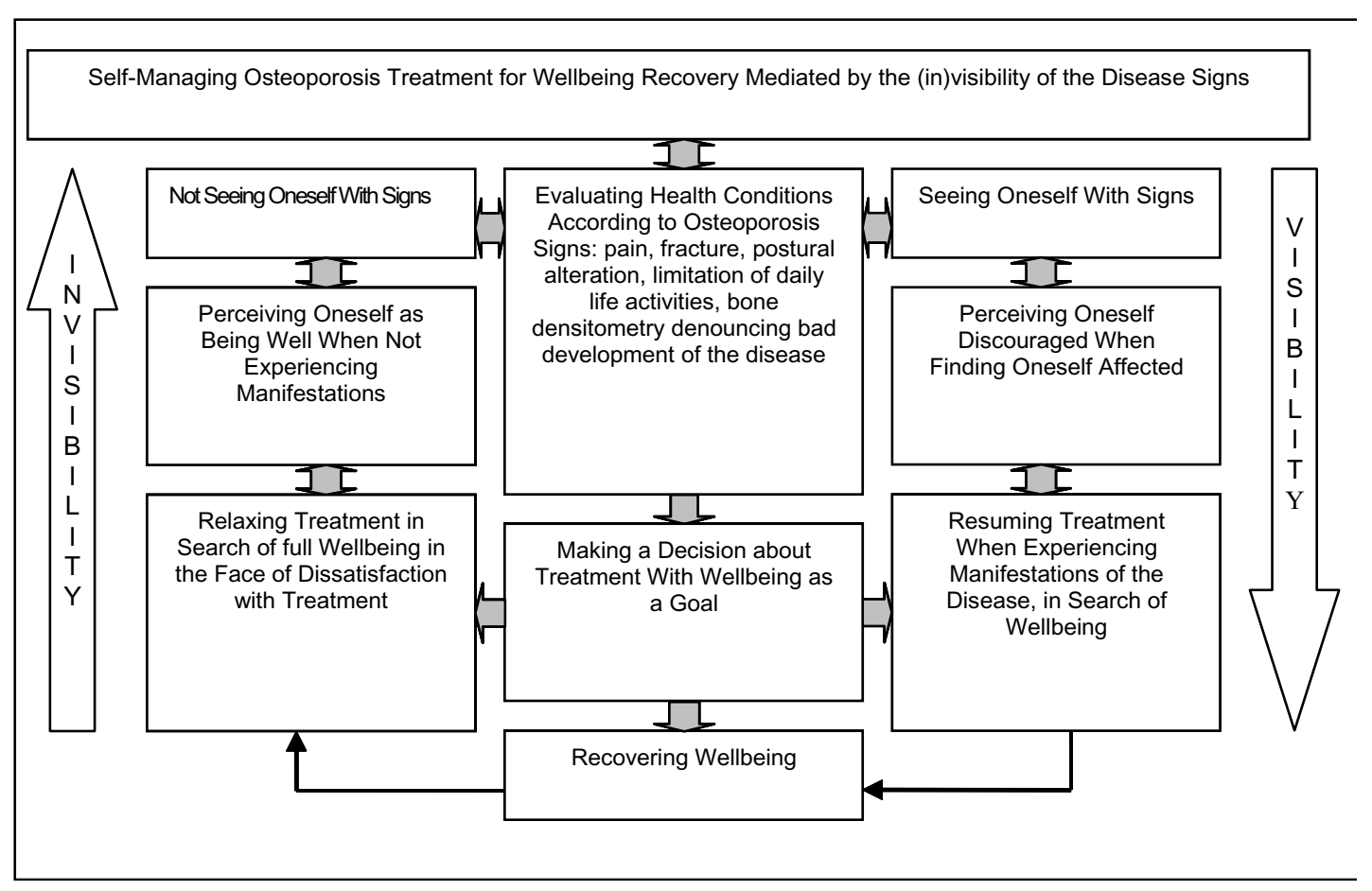

Figure 1 - Core category - Self-managing osteoporosis treatment for wellbeing recovery mediated by the (in)visibility of the disease's signs

\section{Discussion}

Osteoporosis is a skeletal disease characterized by the compromising of bone strength, predisposing to increased risk for fractures. The fractures are associated with increased morbidity and mortality, functional loss and psychological consequences. Pharmacotherapeutic interventions in post-menopausal women with osteoporosis result in substantial reduction in fracture risks. The importance of nutritional support, appropriate exercises and cessation of smoking habits and excessive alcohol use should also be emphasized. Despite the efficacy of therapy with medication agents, most patients who initiate treatment do not adhere to it for longer than a year. Hence, one of the key factors for fracture risk reduction consists in the development of strategies directed at increased treatment adherence ${ }^{(3)}$.

The conduction of this study has shown that the experiences of individuals with osteoporosis undergo a cyclic movement between treatment relaxation and resumption aiming for wellbeing, which is mediated by the visibility or not of the disease, according to their interaction with signs and symptoms correlated with the disease.
The fact that the individual continually self-evaluates his health conditions, based on the presence or absence of signs (symbols) of osteoporosis manifestation, such as: pain, fracture, postural alteration, limitations to activities of daily living and bone densitometry denouncing the progression of the disease, are central factors for the individual to make a decision to resume or relax treatment.

According to Symbolic Interactionism, an individual's definitions and judgments are highly dependent on the social definitions that he encounters during his lifetime. Hence, the actors in this investigation conceive the health-disease process as the absence and presence of signs and symptoms of the disease, setting away any health-promotion and disease-prevention interventions. It is true that the concept of health is questionable, but if even researchers in the field have in vain attempted to accurately define it, causing it to remain as a blind point in epidemiology ${ }^{(14)}$, what to say about the general population?

It is for this reason that an individual's decision to resume treatment is made after he understands that he 
is affected by the disease, when he concretely perceives himself as having signs and symptoms. When he does not perceive them, osteoporosis is placed in an invisible position. Therefore, the individual relaxes the treatment aiming to achieve full wellbeing, especially when he experiences side effects from medication or because he considers that the recommended diet is not within his consumption possibilities in the following situations: non-palatable, expensive types of food, or because they present intolerance to lactose. In fact, although the side effects related to the use of medication against osteoporosis are not frequently discussed, they exist(15) and may, at least partially, be responsible for treatment abandonment. Hence, when selecting the therapeutic scheme to be used, one of the most important aspects to be evaluated is the risk-benefit relationship of each drug. As to diet, it is clear that calcium (Ca)-rich types of food in particular play a fundamental role in osteoporosis prevention and treatment. The content and bioavailability of this mineral vary considerably in different food types, and a large number of factors influence its absorption. Cow milk and dairy products are the richest sources with the highest $\mathrm{Ca}$ absorption. However, other types of food, such as white beans, broccoli, kale and whole small fish could be used in association with products of higher content/bioavailability, in order to achieve adequate dietetic Ca goals in individuals who do not want or cannot ingest cow milk ${ }^{(16)}$. As regards the cost of the required diet, community programs aiming at adequate food intake, in addition to local socioeconomic development, should be encouraged to prevent and treat a large number of nutrition-related diseases, among which osteoporosis.

According to Symbolic Interactionism, interaction with oneself and others makes an individual make decisions that direct his course of action. It is the definition of the situation established by the actor that is central to how the action will occur(13). Therefore, it is necessary for the individual to reconfigure himself, giving himself the opportunity to share the knowledge of professionals as well as the experiences of other patients who have been through similar situations. Consequently, it would be recommended that health care professionals: a) promote therapeutic actions by means of operating groups working towards health education, aiming to encourage people to reflect on the cyclic process of self-evaluation expressed in the model and the adoption of a new conception in the healthdisease process, health promotion and prevention of complications. This strategy has shown to be effective in the treatment of other chronic diseases, such as diabetes mellitus(17). To that end, professionals need educational knowledge concerning the communication process, such as the capacity to listen, understand and negotiate. According to the authors, group dynamics stimulate the interpersonal relationship between patients and health care professionals, facilitating discussion among individuals with the same objectives and enabling information exchange. Group members share common experiences that help to understand the disease by making it possible to express doubts and expectations, leading to mutual support; b) attempt to place themselves in the role of the individual with osteoporosis in order to understand the meaning of the words and actions taken in the attempt to locate him in the cyclic movement of the experience (theoretical model). For instance, an individual who comes to the clinic and reports wellbeing is probably going through a phase of greater vulnerability to interrupt treatment so as to experience full wellbeing, particularly when he has a history of suffering from side effects due to medication treatment or difficulties to follow a recommended diet; c) use the theoretical model found not only as an instrument to attempt to find the direction that an individual has adopted or is adopting, but also as an educational technology in order to work on the individual's (group's) behavior in relation to the treatment, aiming to show how the experience of people undergoing osteoporosis treatment is configured and how non-adherence implies a retrocession in the therapeutic process of the disease; d) understand that the process of coping with nonadherence to osteoporosis treatment goes beyond prescriptive activities for medication and non-medication therapies. It is necessary to adopt educational actions within an understanding and multiprofessional approach by taking the biopsychosocial paradigm into account.

By analyzing the theoretical model discovered, "Self-managing osteoporosis treatment for wellbeing recovery mediated by the (in)visibility of the disease signs", in the light of already existing knowledge, we have realized that it corroborates the findings of previously conducted studies, as described in the introduction ${ }^{(6-9)}$. However, it seems that its major contribution may be configured as a light-technology prototype for health care professionals to help individuals with osteoporosis evaluate themselves in relation to treatment adherence, as well as to lead them to a better visualization of their interaction between relaxation (phase of invisibility of symptoms and signs) and the susceptibility to regress in treatment of the disease, as well as the possibility 
to improve its signs and symptoms by adhering to treatment (phase of visibility of the disease).

It is also noteworthy that non-structured interviews constitutethemain data collection instrumentsinqualitative healthcare research. These studies are consolidated in the literature ${ }^{(18)}$ and offer important contributions to the quality of evidence-based practice(19).

\section{Concluding Remarks}

The use of the Grounded Theory as a methodological basis and of Interactional Symbolism as a theoretical framework has enabled us to understand the experience of patients with osteoporosis undergoing treatment for the disease. It allowed for the construction of a theoretical model that facilitates the creation of strategies for therapeutic interventions, according to the moment experienced by the individual. We suggest the conduction of epidemiological case-control studies to evaluate the impact of using this model as a healtheducation technology, so as to act on osteoporosis patients as a continuous "reminder", paying attention to their struggle in following the treatment proposed by the multiprofessional health care team.

\section{References}

1. Ministério da Saúde (BR). [homepage na Internet]. Brasília: Ministério da Saúde; [acesso em 06 maio 2008]. Programas e projetos: doenças cardiovasculares; [3 telas]. Disponível em: http://www.saude.gov.br.

2. Lebrão ML, Duarte YAO. SABE - Saúde, Bem-estar e Envelhecimento - O projeto SABE no município de São Paulo: uma abordagem inicial. Brasília: OPAS; 2003.

3. Castellar E, Vilar L, Griz L, Lima JG, Nóbrega LHC. Manuseio da osteoporose: uma visão geral. In: Vilar $L$, editor. Endocrinologia clínica. Rio de Janeiro (RJ): Guanabara-Koogan; 2006. p. 843-77. 4. Penrod J. Getting funded: writing a successful qualitative smallproject proposal. Qual Health Res. 2003 July;13(3):821-32.

5. Lekkerkerker F, Kanis JA, Alsayed N, Bouvenot G, Burlet N, Cahall $D$, et al. Adherence to treatment of osteoporosis: a need for study. Osteoporos Int. 2007 October;18(10):1311-7.

6. Baheiraei A, Ritchie JE, Eisman JA, Nguyen TV. Exploring factors influencing osteoporosis prevention and control: a qualitative study of Iranian men and women in Australia. Maturitas 2006 May; 54(2):127-34.

7. Jachna CM, Forbes-Thompson S. Osteoporosis: health beliefs and barriers to treatment in an assisted living facility. J Gerontol Nurs. 2005 January; 31(1):24-30; quiz 42-3.

8. Giangregorio L, Dolovich L, Cranney A, Adili A, Debeer J, Papaioannou $A$, et al. Osteoporosis risk perceptions among patients who have sustained a fragility fracture. Patient Educ Couns. 2009 February; 74 (2):213-20.

9. Sedlak CA, Doheny MO, Estok PJ, Zeller RA, Winchell J. DXA, health beliefs, and osteoporosis prevention behaviors. J Aging Health. 2007 October; 19(5):742-56.

10. Sharts-Hopko NC, Sullivan MP. Beliefs, perceptions, and practices related to osteoporosis risk reduction among women with multiple sclerosis. Rehabil Nurs. 2002 November-December; 27(6):232-6.
11. Giangregorio L, Papaioannou A, Thabane L, DeBeer J, Cranney $A$, Dolovich $L$, et al. Do patients perceive a link between a fragility fracture and osteoporosis? BMC Musculoskelet Disord [serial on the internet]. [cited 2008 March 21]; 9:38:[about 9 p.]. Available from: http://www.biomedcentral.com/content/ pdf/1471-2474-9-38.pdf.

12. Strauss A, Corbin J. Basics of qualitative research: techniques and procedures for developing grounded theory. Thousand Oaks (CA): Sage Publications; 1989.

13. Charon JM. Symbolic interactionism: an introduction, an interpretation, an integration. Englewood Cliffs (NJ): Prentice Hall; 1989.

14. Almeida $\mathrm{N}$ Filho. O conceito de saúde: ponto-cego da epidemiologia? Rev Bras Epidemiol abril-dezembro 2000; 3(13):4-20.

15. MacLean C, Newberry S, Maglione M, McMahon M, Ranganath $V$, Suttorp $M$, et al. Systematic review: comparative effectiveness of treatments to prevent fractures in men and women with low bone density or osteoporosis. Ann Intern Med. 2008 February; 148(3):197-213.

16. Buzinaro EF, Almeida RNA, Mazeto GMFS. Biodisponibilidade do cálcio dietético. Arq Bras Endocrinol Metabol outubro 2006; 50(6):852-61.

17. Torres HC, Hortale VA, Schall V. A experiência de jogos em grupos operativos na educação em saúde para diabéticos. Cad Saúde Pública. julho-agosto 2003; 19(4):39-47.

18. Fontanella BJB, Campos CJG, Turato ER. Data collection in clinical-qualitative research: use of non-directed interviews with open-ended questions by health professionals. Rev. Latino-Am. Enfermagem September-October 2006; 14(5):812-20.

19. Ailinger RL. Contributions of qualitative research to evidencebased practice in nursing. Rev. Latino-Am. Enfermagem. June 2003; 11(3):275-9. 